\title{
NAC TRANSCRIPTION FACTORS ROLE IN VARIOUS BIOTIC AND ABIOTIC STRESSES
}

Hafsa Mansoor ${ }^{1}$, Nadia Iqbal ${ }^{1}$, Maryam Zain ${ }^{1}$, Farah Deeba ${ }^{1 *}$

${ }^{1}$ Department of Biochemistry and Biotechnology, The Women University, Multan, Pakistan

\section{Corresponding Author}

Dr. Farah Deeba

Department of Biochemistry and Biotechnology, The Women University, Multan, Pakistan farah.9003@wum.edu.pk

\begin{abstract}
NAC transcription factors are considered as main family of transcriptional regulators in plants. NAC gene family members play significant contribution in regulating transcriptional reprogramming in plants related to plant stress response. These proteins possess highly conserved DNA binding domains and play a diverse functions in several plants. NAC gene is related to several stress factors including biotic and abiotic factors. NAC transcription factors controls several interrelated processes and their protein products can function as negative or positive regulators in many cellular processes. These regulatory functions are also controlled by NAC proteins such as auto and cross regulation. These regulatory proteins are regarded as a central regulator for the interaction of phyto hormones in various stress signaling pathways. This review highlights the role of NAC transcription factors in modulating gene expression and their role in various biotic and abiotic stress tolerance in plants.
\end{abstract}

\section{Key Words:}

Transcription factor, NAC, stress response, biotic stress, abiotic stress.

\section{INTRODUCTION}

Transcription factors (TFs) and their interaction with promoter regulatory sequences are necessary to regulate gene expression in plants and animals. There are about 2500 genes in 
Arabidopsis genome encode for various transcription factors (1). There are large numbers of transcription factors related to regulation of genes in plants. The main families include $N A C$ \{No apical meristem (NAM), Arabidopsis transcription activation factor (ATAF), Cup-shaped cotyledon (CUC) \}. Various isoforms of NAC family have been recognized and categorized in model plants like Arabidopsis (2,3), crops like Oryza sativa(4,5)soybean (Glycinemax) $(6,7,8)$ and wheat (Triticum species) (9) and in certain typical tree classes like Populus trichocarpa (10) and citrus (Citrus sp.) $(11,12)$.Extensive research supported by the study of genomic sequences of various plants identified 117 NAC genes in Arabidopsis, 79 in Vitis vinifera, 151 in rice, 163 in Populus trichocarpa and 152 in tobacco and soybean, making them a major group of TF's in plants.

\section{Structural Characteristics}

Typically, NAC proteins consist of two motifs located at both $\mathrm{N}$ and $\mathrm{C}$ - termini. N-terminal motif is conserved and comprise of 150 amino acids while C-terminal transcription regulatory (TR) regions are highly variable (Figure 1 (i))(13). Along with these structural motifs, some uncommon modifications in NAC assembly has also been observed [Fig 1 (ii-vi)]. One domain of $N A C$ codes for 1 NAC protein $(14,15)$ and two tandem repeated NAC domains(16). SOG1 genes are extended by the N-terminal motif $(16,17)$ and are made up of NAC and Vascular plant One-Zinc finger proteins, which includes DNA binding (db), zinc finger, C-terminal NAC region and $\mathrm{N}$-terminal TR region $(13,16)$.

\section{NAC Domains}

NAC domain is recognized by its DNA binding ability and is divided into 5 subdomains (A-E, Fig 1). Each subdomain is highly conserved and have diverse properties related to structure. Functional analysis reveal that subdomain $\mathrm{A}$ is involve in the synthesis of functional dimer, subdomain $\mathrm{B}$ and $\mathrm{E}$ are distinct and shows the functional variation in NAC genes in different plants. Subdomain C contains positively charged amino acids and is highly conserved domain while subdomain D has ability to bind the DNA $(16,18)$. According to a report, 15 variants (AO) of NAC protein have been identified in rice that are different in their structures based on their amino acid domains(19). Type A - E contains five motifs that are present in standard NACDNA binding domain, and type $\mathrm{F}$ - O consists of a distinct motif conformation in ' NAClike ' proteins. Due to structural variations in various motifs, these proteins shows possibly diverse functions and have unidentified specificities. 


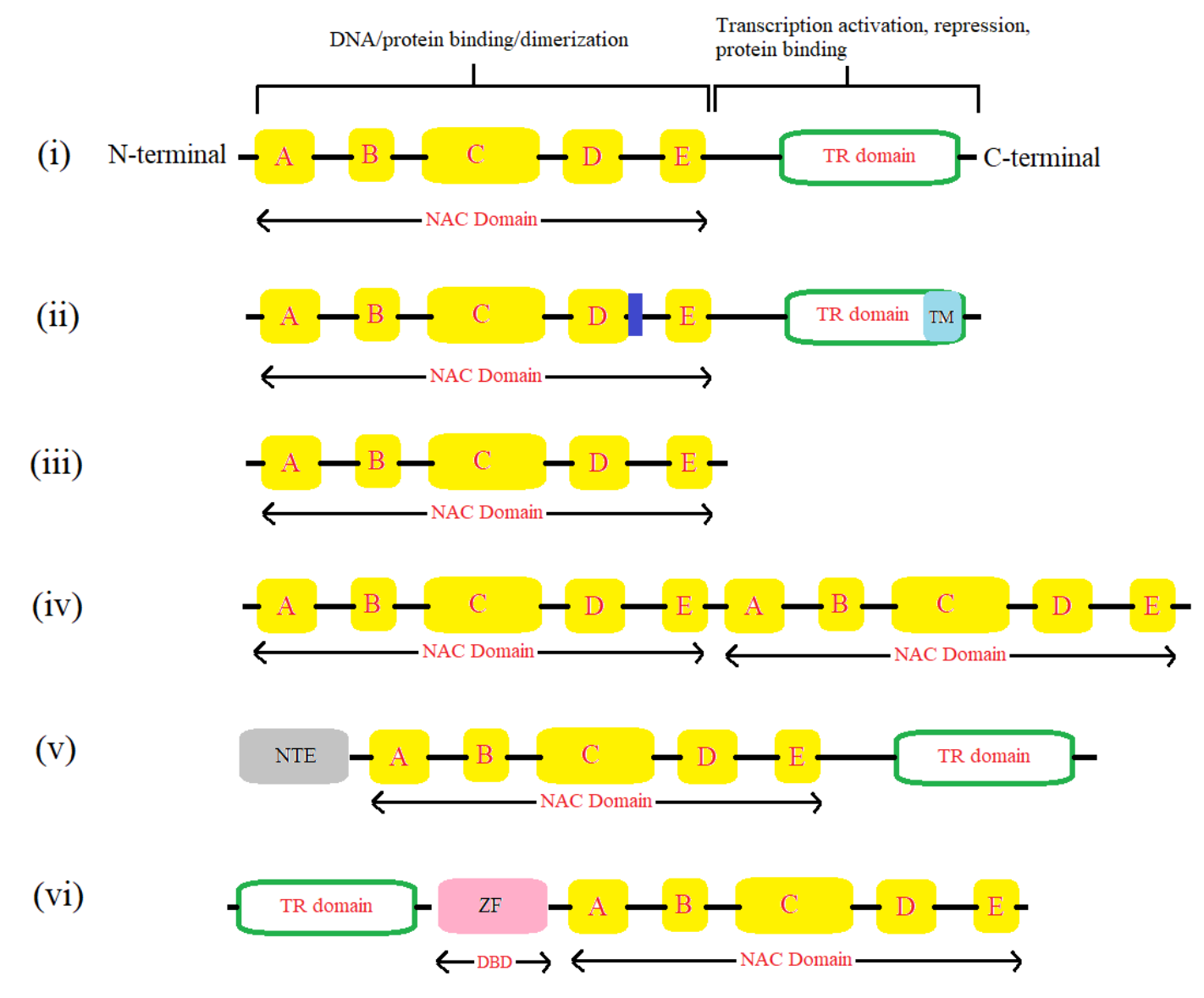

Figure 1: Structure and regulation of NAC proteins: Diagrammatic description demonstrate (i) a standard NAC protein at the N-region with aextremely conserved NAC motif that is sub-divided into five conserved subdomains (A - E).This zone containsDNA binding ability that follows protein binding and dimerization. C-terminal is diverse and supports an activator or repressor-functional transcriptional regulatory (TR) dominant domain which may often carry protein binding activity. (ii)In various circumstances a trans membrane motif (TM) in the Cterminal is found in the NAC domain and a blue shaded negative control domain. Changes in standard NAC proteins contain those programming(iii) the NAC motifs, (iv) two tandemly repeated NAC motif, (v) a N-terminal extendedarea (NTR) moving towards NAC domain (vi) Vascular plant One-Zinc fingerproteins (VOZ), where the NAC region is located at the $\mathrm{C}$ terminal and the TR region is located at the N-end with a zinc finger motif (ZF) working as a conserved DNA binding domain.

\section{X-ray Crystal Structure}

After studying crystallography and insilico investigation in Setaria italica SiNAC, Arabidopsis thalianaAtNAC019 and in Oryza sativa stress-responsive NAC1 (SNAC1) proteins, it is revealed that these transcription factors are comprised of a twisted b-sheets (b1-6/7) that are antiparallel, used for DNA binding and positioned between an N-extreme of alpha turn and a short helix $(18,20)$. Amino acid composition of DB domain reveal that 19 to Serine183, b4 to 6 zone D-E, Lysine123 and Lysine126, b4-5 zone D and Lysine79, Arginine85 and Arginine88, 
b1-2 zone C $(13,18)$.In DNA binding affinities, Lysine79 and Arginine85 are distinct so that they are exchangeable residues whereas Arginine is 88 is retained in all NAC proteins (16).

In fact, the protein binding action of NAC transcription factors regulates the fate and role of the NAC protein $(13,24)$. These interactions are important between plants and pathogens as well as in stress tolerance (21).The $\mathrm{D}$ subunit is extremely hydrophobic negative regulatory domain (NRD) in some NAC proteins, which limits transcriptional activity [Fig 1 (ii)]. Even other TF families such as DNA-binding with one finger (Dof), WRKY and AP2/DRE can be suppressed by the NRD-like sequences (8).

\section{NAC Transcription Regulatory Regions (TRRs)}

Structural analysis reveal that transcription regulatory regions (TRRs) are usually located at Cterminal (Figure 1 (i)). These regions can stimulate (22) or suppress the rate of transcription of various genes $(23,24)$. The Transcriptional regulatory regions have conserved amino acid sequences that are abundant in Ser-Thr, Pro-Glu repeats or acidic amino acids. It is identified that ten TRR regions are present in NAC proteins in rice(19).It has shown that these regions are similar for subgroups of NAC subdivision but there is variation across different subdivision(14). Thus, TTRs shows modifications according to specific roles of NAC proteins in different plants. Due to the less complicated sequences, transcription regulatory region contains a high level of intrinsic dysfunction (ID) and it does not contain any stable 3D structure $(16,25)$. This flexibility facilitates the formation of model proteins by interacting them with different target proteins for structural and TF functional analysis. The TTR's of some NAC proteins have the ability to bind several proteins with it (25). The pattern of alpha-helical trans membrane (TM) found in some NAC proteins (named NTLs) is responsible for anchoring the cell membrane or ER membrane (Fig 1(ii)) (26).

\section{NAC Function and Expression}

NAC transcription factors have role in a number of processes, including plant development(13), secondary wall synthesis $(27)$ maturity $(25,28)$, biotic $(13,29)$ and abiotic stresses(30,31).The genome-wide transcriptome study and bioinformatics study shows 20 to 25 percent of NAC genes working at least in one stress response or another $(19,32)$. 
Diversity of molecular mechanisms regulates the localization of eukaryotic transcription factors, one of which by allowing nuclear localization of the transcription factor. Precursor cleavage have two mechanisms, one is regulated intramembrane proteolysis and other is regulated ubiquitinproteasome dependent processing (95). Some transmembrane prediction programs predict that TIP consist of transmembrane region. Nucleocytoplasmic shuttling guided by nuclear localization signals (NLSs) (96) and nuclear export signals (NESs) (97) can also regulate the activity of transcription factors. Five NAC proteins have been shown to localize to the nucleus $(3,94)$. Several NAC sequences are predicted to contain an NLS when analysed by PredictNLS (98) and PSORT (99). Though, no single conserved NLS site is visible with these prediction tools. Using the NES prediction tool NetNES (100), some NAC sequences are predicted to have an NES in a region of the NAC domain that is rich in conserved hydrophobic amino acids e-g residues 43-51 in AC019.

Box 1. Regulation of nuclear localization of NAC transcription factors

\section{NAC Regulation and Activity}

\section{Transcriptional regulation}

Transcription factors have role in regulation level of transcription (Figure 2). Studies of leaf to protoplastic evolution indicated that multi-potential advances includes triggering multiple silent $N A C$ genes $(33,34)$. Other example is the NACnrp1, endosperm, controlled by genomic imprinting .Patrilineal transferred alleles are therefore suppressed, permitting maternal regulation of the production of endosperm (35).

\section{Post-transcriptional regulation}

miRNAs are small RNAs with a regulatory association to the targeted mRNAs which allow the targets to be repressed after transcription (36). Computer analysis shows that transcription factors implicated in the determination of cell-fate are the primary objectives of miRNAs in plants(37). Initially, a subclass of Arabidopsis NAC mRNAs including CUC1, CUC2, Nacl, $5 g 07680$ mRNA's and CUC1 and CUC2 were estimated as a targeting component of the miR164 gene family, and their additional miR164 sites were blocked (38). However, the miR164 expression resistant for CUC1 and CUC2 mRNA's and miR164 overexpression showed that miR164 is compulsory in order to regulate the CUC1 and CUC2 correctly. miR164-directed NAC1, At5g07680 and At5g61430 were identified by representing the significance of post-transcription regulation of different NAC genes $(39,40)$. Another regulation point at the RNA level is the long term phloem transference of the NAC mRNA CmNACP in Cucurbita maxima. A pathway that integrates physiological processing in the 
distant organs with development in meristematic tissue, $C m N A C P$ mRNA is shifted from plant body to shooting apex (41) (Figure 2).

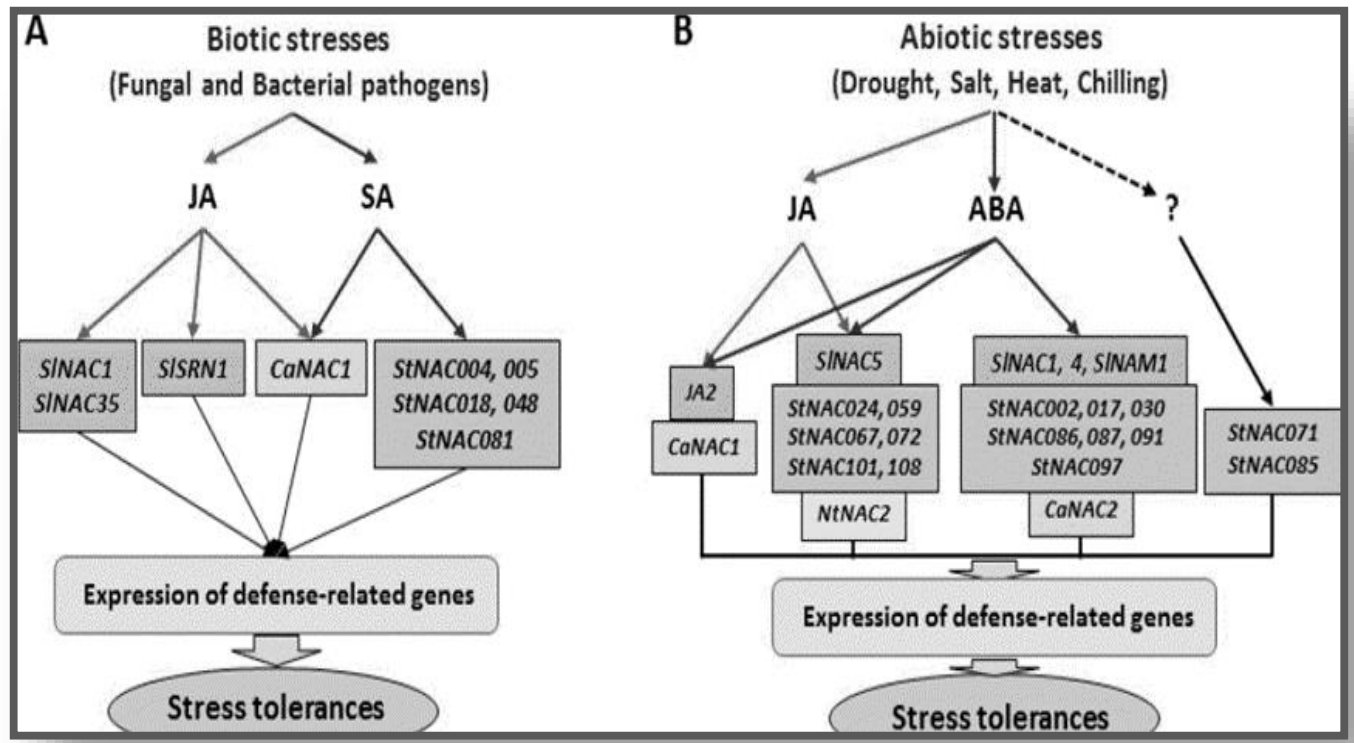

Figure 2: The function of NAC TF's in the signaling pathway for herbivores / biotic and abiotic.

\section{Post-translational regulation}

Post translation regulation by ubiquitine-mediated protein degradation is also used to control the NAC activity (42). The degradation of proteins is targeted by the poly ubiquitation of the proteins E1, E2 and E3 by sequential action (43). SINAT5 (Arabidopsis thaliana 5 SINA) was established as an interaction partner of NAC1 with a yeast 2 hybrid screening(42). SINAT5 has been demonstrated to act as an E3 protein ligase and targeted for NAC1 in order to degrade proteasomes (Fig. 2).

\section{NAC Function in Abiotic Stress}

During stress response in plants, the NAC TF's acts as an important component of various ssignaling pathways. Various plants have moderately a huge range of NAC transcription factors and shows their diverse and unknown functions under various environmental stimuli, and finding their role in abiotic stress is considered a major challenge. In recent studies, NAC protein may have been indirectly involved in abiotic stresses from transcription modeling and functional studies. In general, the facts presented here summarizes the role of various NAC 
transcription factors in controlling transcriptional reprogramming to plant's abiotic stresses (Fig. 3, Table 1).

During plant stress response,NAC proteins act as an important component in the diverse sign aling pathways. Various plants have relatively large numbers of NAC transcription factors and their diverse and unknown roles in complex environmental stimuli and finding their role in abiotic stress is considered as big challenge. The strict modulation of NAC in plant stress conditions participate in the development of diverse signaling networks and prospective candidates for stress tolerance are the significant function of $N A C$ for herbal abiotic stress responses.

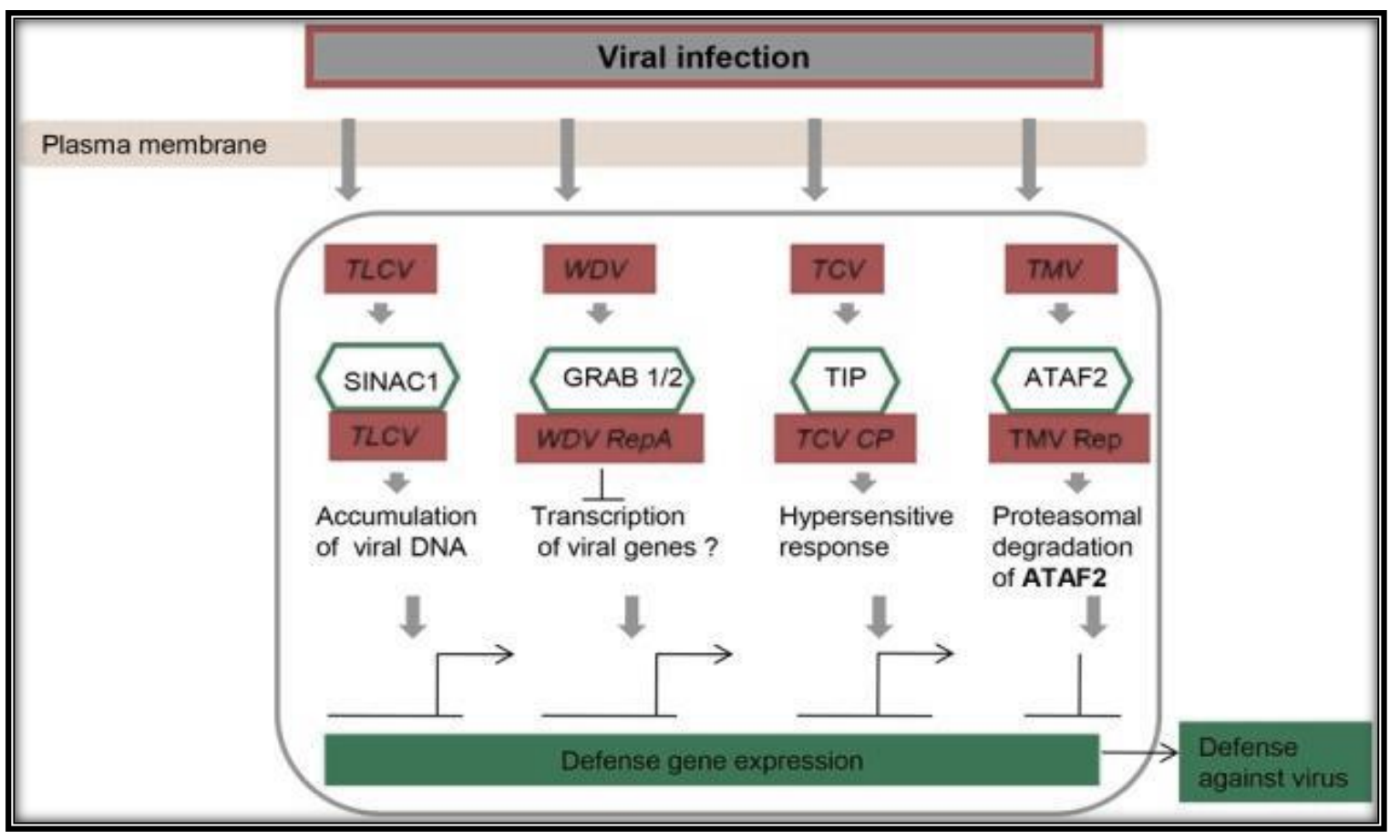

Figure 3: Factors of NAC transcription are key components of gene expression transcriptional regulation in viral diseases.

Abbreviations: WDV (wheat dwarf geminivirus), TCV(turnip crinkle virus); TIP (TCV-interacting protein). TLCV (tomato leaf curl virus), TMV (tobacco mosaic virus).

Abiotic stresses cause a wide spread range of reaction in plants, from changes in the expression of gene and cell metabolism to modifications in plant progress, reproduction and yield performance. Desiccation and $\mathrm{NaCl}$ sensitivity in transgenic Oryza Sativa has been increased after overexpression ofOs01g66120/OsNAC2/6 and Os11g03300/OsNAC-10 (44, 45). It has 
also reported that overexpression of Os03G60080/SNAClresulted in improvement of plant growth from 21 to $34 \%$ under low water availability (4). Comparative expression studies of genes has been identified as an effective method to recognize stress response pathways and genes under different stress conditions (46). A complete relationship has been identified in the Arabidopsis NAC gene ANAC092 (47), during seed maturation and salt-promoting senescence. Various studies revealed that a significant part of dehydration-regulated genes are also fertilization-regulated; pollen is still the main spot of variability in rates of expression among various genes $(48,49)$.Subsequent studies focused on the GUS-promoter fusions for rice and Arabidopsis of cold inducing genes (Os01g66120/SNAC2/6, Os11g03300/OsNAC10 and RD29A, COR15A and COR6.6) were found to upregulated under both stressed and under stressed conditions and during the plant growth $(45,50)$. OsOAT is a target gene of NAC stress inducing transcription factor. SNAC2and OsOAT overexpression in Oryza Sativa has contributed to a significantly increased during drought and osmotic stress conditions (51). Plants that over-express GmNACO85 show increased tolerance to drought (7) whileGmNAC11 overexpression has directed to increase $\mathrm{NaCl}$ and mannitol stress tolerance (8). The activation of 17 NAC genes under low water potential has been reported by microarray analysis in rice roots (52).Over expression of SiNAC from foxtail millet has also resulted during various stresses including drought, high salt concentration, and methyl jasmonate (20). Transgenic Tobacco (Nicotiana tabacum) transformed with various NAC genes including DgNACl, TaNAC2 $a$ and EcNAClisolated from bacteria and higher plants showed tolerance to salinity and drought conditions $(53,54,55)$.

\section{NAC Role in Biotic Stress}

Various studies regarding NAC transcriptionfactor show the significance of various members of the multigene family in the transcriptional reprogramming of the plant immunized response.The research has been reviewed extensively and will therefore be briefly examined here.Apparently, the NAC TF's are the main elements of different characteristics in the innate immune system, essential defense and complete resistance of a crop. This is an important field of research that has been thoroughly examined and is thus only mentioned shortly here. Apparently, NAC TF's are essential components for many aspects of the endogenous, fundamental and systemic immune system in plants. 4; Table 2) $(16,56,57)$. In order to assess function of NAC transcription factors (ONAC122 and ONAC131) in M. grisea resistance disease, Sun and 
co-workers used VIGS systems (58). Virus-induced gene silencing is a valuable tool for fast genetic feature investigation in plants $(59,60)$. Virus-induced gene silencing have been established for dicot species, in which the tobacco virus based VIGS vector for Solanum, tobacco and the tomato is a most successful model (61). The VIGS vector of barley stripe mosaic virus is used to elucidate the role of several genes in wheat and barley disease resistance (50). Researchers have created a brome mosaic vector based VIGS, which has been shown to be a powerful method to rapidly evaluate the gene function of barley, rice and maize $(62,63)$.

There are several cases of overexpression or low NAC gene expression influencing plant defence, which have enabled some components of the signal pathway to be resolved (Figures 3, In germinating rice seedlings 19 and 13 genes have been upreglated after RSV and RTSV inflammations at several days of inoculations, respectively (32). Many NAC proteins have been shown to over expressed as a result of attacks by viruses, various fungal elicitor and bacteria that may both increase or decrease the viral growth by interacting with virus-encrypted proteins and increase in NAC expression levels $(9,64,65,66)$. The interaction of NAC proteins with different regulatory network is a consequence of this dual regulation in plant defense. OsNAC4 is the main positive regulator for hypersensitive plant cell death, with dramatically declining hypersensitive cell mortality as a consequence of non-infectious bacterial strains on OSNAC4 knock-down line. OSNAC4 will be transferred to the nucleus according to the phosphorylation after inducing virulent pathogens perceiving signal.

On the other side, the $O s N A C 6$ overexpression does not result in hypersensitive cell mortality (67), whileOsNAC6 over-sensitive Oryza sativa plants has the ability to tolerate blast disease (68). An increased sensitivity of ATAF2 overexpression against the parasitic infection Fusarium oxysporum during proper situations due to pathogenesis associated suppression (69), which contributed to an enhanced vulnerability for pathogenesis-related (PR) genes caused to the non-sterile aggregation of tobacco mosaic viruses (66). The role of NAC transcription factors in several plant-patent association has also been identified in RNA interference and overexpression analysis $(67,70)$. The role of ATAF1 and its Barley Homolog HvNAC6 has also been shown to positively control penetration susceptibility to Blumeria graminisf.sp. biotrophic fungus RNA studies and over-expression findings. The aim is to reduce resistance for various diseases, including Bacterial, and fungal diseases $(56,57)$. 
Table 1: NAC TF's families involved in abiotic stress-responsive pathways in plants

\begin{tabular}{|c|c|c|c|c|}
\hline Species & Genes & Functions & Method & References \\
\hline O. sativa & OsNAC5/Os1 lg08210 & $\begin{array}{l}\text { ABA, salt, cold } \\
\text { tolerance, grain } \\
\text { filling }\end{array}$ & Overexpression & $(76)$ \\
\hline O. sativa & ONACO4/Os1 lg033005 & $\begin{array}{l}\text { Drought, salt, cold } \\
\text { tolerance }\end{array}$ & Overexpression & $(77)$ \\
\hline O. sativa & OsNACIOOS11g03300 & $\begin{array}{l}\text { Root, panicle, } \\
\text { drought, salt, ABA }\end{array}$ & Overexpression & $(45)$ \\
\hline O. sativa & Ostill & Shoot branching & Overexpression & $(101)$ \\
\hline O. sativa & SNAC1/Os03g6008O & $\begin{array}{l}\text { Stomata close, } \\
\text { higher } \\
\text { seed setting }\end{array}$ & Overexpression & $(4)$ \\
\hline O. sativa & $S N A C 2 / O s N A C 6 / O s 01 g 66120$ & $\begin{array}{l}\text { Salt, drought, } \\
\text { disease resistance } \\
\text { drought, } \\
\text { salinity, cold, } \\
\text { wounding, and } \\
\text { abscisic acid } \\
\text { (ABA) treatment }\end{array}$ & Overexpression & $(50)$ \\
\hline O. sativa & RIMI/Os03g02800 & $\begin{array}{l}\text { JA pathway } \\
\text { signaling }\end{array}$ & Mutant & $(78)$ \\
\hline O. sativa & Os07g04560, Os $10 \mathrm{~g} 38834$ & Root, severe drought & Microarray & $(52)$ \\
\hline N. tabacum & TaNAC2a & Drought tolerance & Overexpression & $(55)$ \\
\hline N. tabacum & $D g N A C l$ & $\begin{array}{l}\mathrm{ABA}, \mathrm{NaCl} \text {, drought } \\
\text { and cold }\end{array}$ & Overexpression & $(53)$ \\
\hline $\begin{array}{l}\text { G. } \max \\
\text { A. thaliana }\end{array}$ & $\begin{array}{l}\text { GmNAC20, DREB1A/CBF3, } \\
K I N 2 / \operatorname{cor} 6.6, \operatorname{Cor} 15 A, \\
R D 29 A / \operatorname{cor} 78, A R F 19, \\
\text { LBD12, } \\
\text { AIR1 }\end{array}$ & $\begin{array}{l}\text { Salt and freezing } \\
\text { tolerance }\end{array}$ & Overexpression & $(8)$ \\
\hline A. thaliana & NTL $S$ & $\begin{array}{l}\text { Salt tolerance, GA, } \\
\text { and ABA pathway }\end{array}$ & Gene expression & $(79)$ \\
\hline A. thaliana & $A N A C 019, A N A C 055$ & $\begin{array}{l}\text { Defense disease, JA } \\
\text { pathway }\end{array}$ & Overexpression & $(80)$ \\
\hline A. thaliana & $\begin{array}{l}\text { anac092-1, ANACOS3, } \\
\text { ANACO41, } \\
\text { ANACO54, ANACOS4 }\end{array}$ & $\begin{array}{l}\text { Positive regulator of } \\
\text { seed germination } \\
\text { under } \\
\text { salinity }\end{array}$ & Mutant & $(47)$ \\
\hline A. thaliana & $n t l s-1$ & $\begin{array}{l}\text { Positive regulator of } \\
\text { seed germination } \\
\text { under } \\
\text { salinity }\end{array}$ & Mutant & $(79)$ \\
\hline A. thaliana & $\begin{array}{l}\text { ATAF1, COR47, ERDIO, } \\
\text { KIN1, } \\
\text { RD 22, RD29A }\end{array}$ & $\begin{array}{l}\text { Positive regulator of } \\
\text { drought tolerance }\end{array}$ & $\begin{array}{l}\text { knochouts (atafl- } \\
1 / 2 \text { ) }\end{array}$ & $(81)$ \\
\hline T. aestivion & $\begin{array}{l}\text { TaNAC2a, TaNAC4a, } \\
\text { TaNAC6, } \\
\text { TaNAC7, TaNAC13 and } \\
\text { TaNTL5 }\end{array}$ & $\begin{array}{l}\text { Dehydration, salinity } \\
\text { and low temperature }\end{array}$ & Transgenic & (9) \\
\hline T. aestivion & TaNAC4 & $\begin{array}{l}\text { Environmental } \\
\text { stimuli, inclu ding } \\
\text { high salinity, } \\
\text { wounding, and low- } \\
\text { temperature also } \\
\text { induced }\end{array}$ & Transcription & $(82)$ \\
\hline G. $\max$ & $\begin{array}{l}\text { GmNAC11, DREBIA, } \\
\text { ERDI1, } \\
\text { Cor15A, ERF5, RABIS, KAT2 }\end{array}$ & $\begin{array}{l}\text { Salt tolerance in } \\
\text { soybean transgenic } \\
\text { hairy } \\
\text { roots }\end{array}$ & Overexpression & ( 8$)$ \\
\hline G. $\max$ & $\begin{array}{l}G m N A C \text { glycoside } \\
\text { hydrolases, } \\
\text { defensins and glyox al ase I } \\
\text { family } \\
\text { proteins }\end{array}$ & Drought stress & $\begin{array}{l}\text { Soybean array } \\
\text { GeneChip }\end{array}$ & (7) \\
\hline
\end{tabular}

In comparison to $A T A F 2$, transcription-activators are $A T A F 1$ and $H v N A C 6$ and can potentially control PR repression through imaginary negative regulators. Therefore, it seems that the ATAF subfamily has a retained but not obsolete role in regulating reactions to different pathogenic agents. The immune reaction in pathogen-borne plant species is defined by several 
defensive responses that are controlled by the various types of TF such as the production of the significant number of resistance associated genes (71).Arabidopsis NAC genes that are stressresponsive, including RD26 relate to JA, a well-known phytohormone that works to improve plant damage $(3,72)$.

Table 2: Role of NAC transcription factors in stress response

\begin{tabular}{|c|c|c|c|c|}
\hline Species & Genes & Functions & Method & References \\
\hline Oryza $(O)$ sativa & OsNAC4 & $\begin{array}{l}\text { Inducer of HR cell } \\
\text { death up on } \\
\text { Acidovorax avenae } \\
\text { infection, } 1 \text { loss of } \\
\text { plasma membrane } \\
\text { integrity, nuclear } \\
\text { DNA fragmentation }\end{array}$ & Overexpression/knockdown & $(67)$ \\
\hline O. sativa & $\begin{array}{l}\text { OsNAC6, PR protein } \\
\text { 1, } \\
\text { Probenccoleinducible } \\
\text { proteins } \\
\text { (PBZ1s), DUF26-like } \\
\text { Ser/Thr } \\
\text { protein kinase, } \\
\text { Thioredoxin, } \\
\text { Peroxidase, } \\
\text { Lipoxygenase, }\end{array}$ & $\begin{array}{l}\text { Slightly increased } \\
\text { tolerance to rice blast } \\
\text { disease }\end{array}$ & Overexpression & $(68)$ \\
\hline O. sativa & $\begin{array}{l}\text { Os02g34970, } \\
\text { Os02g38130, } \\
\text { Os11g03310, } \\
\text { Os11g03370, } \\
\text { Os11g05614, } \\
\text { Os12g03050 }\end{array}$ & $\begin{array}{l}\text { RSV, RTSV } \\
\text { infections }\end{array}$ & Microarray & $(32)$ \\
\hline$O$. sativa & OsNAC19 & Disease resistance & Infection & $(83)$ \\
\hline O. sativa & $\begin{array}{l}\text { ONAC122 and } \\
\text { ONAC131 brome } \\
\text { mosaic virus (BMV) }\end{array}$ & $\begin{array}{l}\text { Defense responses } \\
\text { against } \\
\text { Magnaporthe grisea }\end{array}$ & --- & $(58)$ \\
\hline G. $\max$ & GmNAC6 & $\begin{array}{l}\text { Responses to biotic } \\
\text { signals, osmotic } \\
\text { stress-induced }\end{array}$ & Transcription & $(84)$ \\
\hline S. tuberosian & Stprx2, StNAC & $\begin{array}{l}\text { Wounding and } \\
\text { pathogen response }\end{array}$ & Transcriptome & $(85)$ \\
\hline A. thaliana & $A T A F 2, N I T 2$ & $\begin{array}{l}\text { Defense hormones, } \\
\text { pathogen infection }\end{array}$ & Overexpression/knockout & $(86)$ \\
\hline A. thaliana & $A N A C 019, A N A C 055$ & $\begin{array}{l}\text { Defense disease, JA } \\
\text { pathway }\end{array}$ & Overexpression & $(80)$ \\
\hline A. thaliana & $\begin{array}{l}\text { ATAF2, PR1, PR2, } \\
P D F 1.2\end{array}$ & $\begin{array}{l}\text { OX = Reduced } \\
\text { tobacco mosaic virus } \\
\text { accumulation, } \\
\text { increased } \\
\text { pathogenesis-related } \\
\text { genes }\end{array}$ & Overexpression/knockout & $(65)$ \\
\hline A. thaliana & $\begin{array}{l}\text { ATAF2, PR1, PR2, } \\
\text { PR4, PR5, } \\
\text { PDF1.1, PDF1.2 }\end{array}$ & $\begin{array}{l}\text { ATAF2 negatively } \\
\text { regulates resistance } \\
\text { to } \\
F \text {. oxysporum, } \\
\text { represses } \\
\text { pathogenesis-related } \\
\text { proteins }\end{array}$ & Overexpression $/$ knockout & $(69)$ \\
\hline A. thaliana & $A N A C 042, P 450$ & $\begin{array}{l}\text { Regulation of } \\
\text { camalexin } \\
\text { biosynthesis, } \\
\text { pathogen infection }\end{array}$ & $\begin{array}{l}\beta \text { - Glucuronidase } \\
\text { (GUS)-reporter assays }\end{array}$ & $(87)$ \\
\hline A. thaliana & NT L4 & $\begin{array}{l}\text { ROS under abscisic } \\
\text { acid, leaf } \\
\text { senescence }\end{array}$ & Transgenic & $(88)$ \\
\hline A. thaliana & NTL9 & $\begin{array}{l}\text { Osmotic stress } \\
\text { responses, leaf } \\
\text { senescence }\end{array}$ & Overexpression/knockout & $(89)$ \\
\hline$M$ truncatula & MtNAC969 & $\begin{array}{l}\text { Symbiotic nodule } \\
\text { senescence }\end{array}$ & Overexpresion & $(90)$ \\
\hline A. thaliana & $V N I 2, O R / R D$ & Leaf senescence & Transcription & $(9 I)$ \\
\hline
\end{tabular}




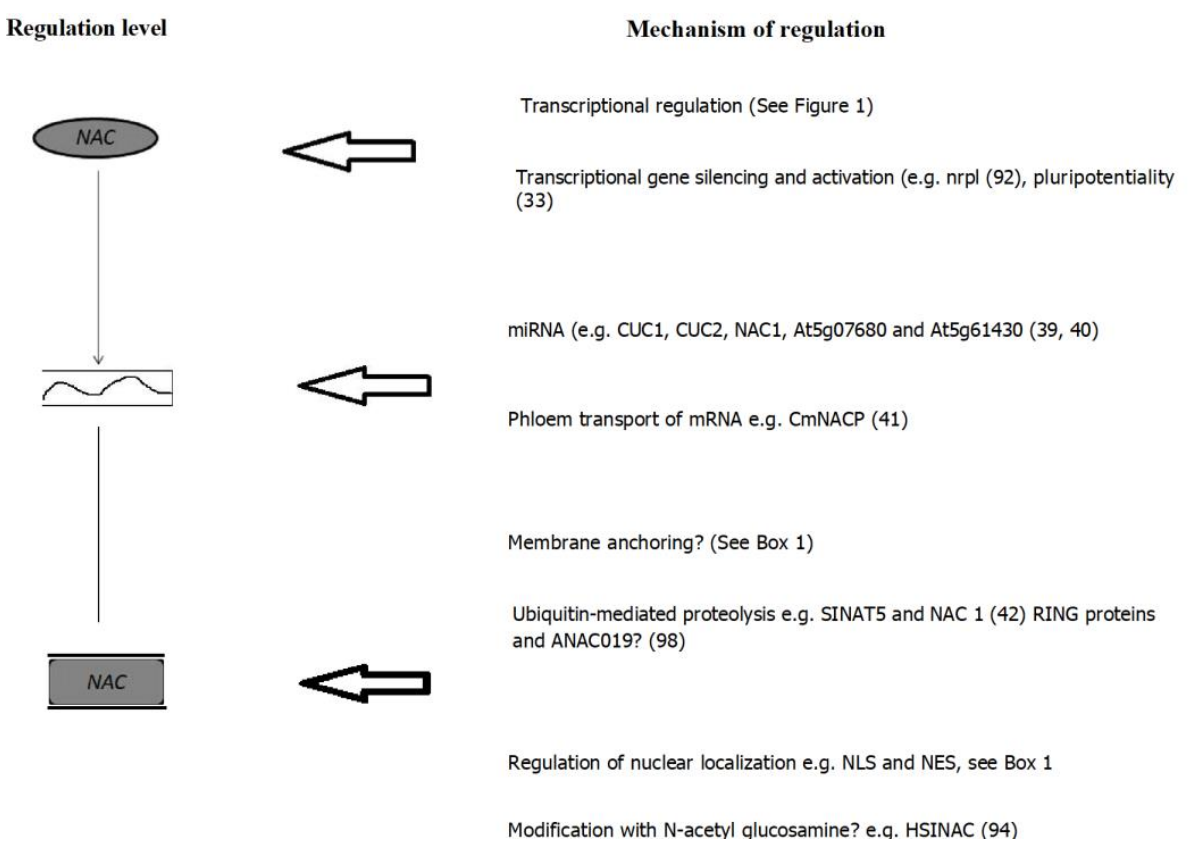

Figure 4. Regulation and location of NAC protein. The regulatory pathway shows the affect of levels of NAC proteins or the position of the protein are described at right side, with the arrows showing the level of DNA, mRNA or protein regulation. Abbreviation: NES (nuclear export signal), HSINAC (HvSPY-interacting NAC), NLS (nuclear localization signal).

\section{Prospects for Future Research}

After the identification of the NAC transcription factor family the study of the physiological a nd molecular roles of NAC protiens was extended further. However, it is still the beginning of this area of research. The occurrence of broad NAC gene families in an extensive variety of plants represents a challenging task in assessing the roles of NAC.

In addition, $N A C$ work would definitely benefit from specific functional review approaches.It is of huge attention to identify targeted NAC genes. One important technique is the overexpression of NAC genes in association with microarray investigation. The TF binding sites of genomic DNA are shown by microarrays in combination with chromatin immunoprecipitation (73). Many knockout mutants are likely to be helpful due to their functional stability. Alternatively, RNA silencing (35) and chimeric repressor silencing $(3,74)$ could also be used. In functional genomics, further analysis of the molecular roles of these transcription factors is important for a better function of NAC protein.

This will also include a detailed examination of NAC protein interactions with DNA and other proteins. In addition to TCP transcription factors, viral proteins and RING proteins, the study of protein-protein interactions can provide important information on plant defense mechanisms, controlled protein degradation and plant growth. In addition, consideration 
should be given to the association of the regulated NAC protein regions with the transcriptional mechanism. The relationship between NAC protein and TCP transcription factors and its ability to dimerize homo and hetro indicates a combinatorial modulation of transcription factor activity (75). So it is obvious that NAC proteins functions with other transcription factors at both upstream and downstream regions. Therefore, a major aim of research on NAC proteins is to brighten up their role in networks of transcription factor.

\section{REFERENCES}

1. Pérez-Rodríguez, P.; Riano-Pachon, D. M.; Corrêa, L. G. G.; Rensing, S. A.; Kersten, B.; Mueller-Roeber, B., PlnTFDB: updated content and new features of the plant transcription factor database. Nucleic acids research. 2010, 38 (suppl_1), D822-D827.

2. Tran, L.-S. P.; Nakashima, K.; Sakuma, Y.; Simpson, S. D.; Fujita, Y.; Maruyama, K.; Fujita, M.; Seki, M.; Shinozaki, K.; Yamaguchi-Shinozaki, K., Isolation and functional analysis of Arabidopsis stress-inducible NAC transcription factors that bind to a droughtresponsive cis-element in the early responsive to dehydration stress 1 promoter. The Plant Cell. 2004, 16 (9), 2481-2498.

3. Fujita, M.; Fujita, Y.; Maruyama, K.; Seki, M.; Hiratsu, K.; Ohme-Takagi, M.; Tran, L. S. P.; Yamaguchi-Shinozaki, K.; Shinozaki, K., A dehydration-induced NAC protein, RD26, is involved in a novel ABA-dependent stress-signaling pathway. The Plant Journal. 2004, 39 (6), 863-876.

4. Hu, H.; Dai, M.; Yao, J.; Xiao, B.; Li, X.; Zhang, Q.; Xiong, L., Overexpressing a NAM, ATAF, and CUC (NAC) transcription factor enhances drought resistance and salt tolerance in rice. Proceedings of the National Academy of Sciences. 2006, 103 (35), 12987-12992.

5. Hu, H.; You, J.; Fang, Y.; Zhu, X.; Qi, Z.; Xiong, L., Characterization of transcription factor gene SNAC2 conferring cold and salt tolerance in rice. Plant molecular biology. 2008, 67 (1-2), 169-181.

6. Tran, L.-S. P.; Quach, T. N.; Guttikonda, S. K.; Aldrich, D. L.; Kumar, R.; Neelakandan, A.; Valliyodan, B.; Nguyen, H. T., Molecular characterization of stress-inducible GmNAC genes in soybean. Molecular Genetics and Genomics. 2009, 281 (6), 647-664.

7. Le, D. T.; Nishiyama, R.; Watanabe, Y.; Mochida, K.; Yamaguchi-Shinozaki, K.; Shinozaki, K.; Tran, L.-S. P., Genome-wide survey and expression analysis of the plantspecific NAC transcription factor family in soybean during development and dehydration stress. DNA research. 2011, 18 (4), 263-276. 
8. Hao, Y. J.; Wei, W.; Song, Q. X.; Chen, H. W.; Zhang, Y. Q.; Wang, F.; Zou, H. F.; Lei, G.; Tian, A. G.; Zhang, W. K., Soybean NAC transcription factors promote abiotic stress tolerance and lateral root formation in transgenic plants. The Plant Journal. 2011, 68 (2), 302-313.

9. Xia, N.; Zhang, G.; Sun, Y.-F.; Zhu, L.; Xu, L.-S.; Chen, X.-M.; Liu, B.; Yu, Y.-T.; Wang, X.-J.; Huang, L.-L., TaNAC8, a novel NAC transcription factor gene in wheat, responds to stripe rust pathogen infection and abiotic stresses. Physiological and Molecular Plant Pathology. 2010, 74 (5-6), 394-402.

10. Hu, R.; Qi, G.; Kong, Y.; Kong, D.; Gao, Q.; Zhou, G., Comprehensive analysis of NAC domain transcription factor gene family in Populus trichocarpa. BMC plant biology. 2010, $10(1), 145$.

11. Liu, Y.-Z.; Baig, M.; Fan, R.; Ye, J.-L.; Cao, Y.-C.; Deng, X.-X., Identification and expression pattern of a novel NAM, ATAF, and CUC-like gene from Citrus sinensis Osbeck. Plant molecular biology reporter. 2009, 27 (3), 292.

12. de Oliveira, T. M.; Cidade, L. C.; Gesteira, A. S.; Coelho Filho, M. A.; Soares Filho, W. S.; Costa, M. G., Analysis of the NAC transcription factor gene family in citrus reveals a novel member involved in multiple abiotic stress responses. Tree genetics \& genomes. 2011, 7 (6), 1123-1134.

13. Olsen, A. N.; Ernst, H. A.; Leggio, L. L.; Skriver, K., NAC transcription factors: structurally distinct, functionally diverse. Trends in plant science. 2005, 10 (2), 79-87.

14. Shen, H.; Yin, Y.; Chen, F.; Xu, Y.; Dixon, R. A., A bioinformatic analysis of NAC genes for plant cell wall development in relation to lignocellulosic bioenergy production. BioEnergy Research. 2009, 2 (4), 217.

15. Christiansen, M. W.; Holm, P. B.; Gregersen, P. L., Characterization of barley (Hordeum vulgare L.) NAC transcription factors suggests conserved functions compared to both monocots and dicots. BMC research notes. 2011, 4 (1), 302.

16. Jensen, M. K.; Kjaersgaard, T.; Nielsen, M. M.; Galberg, P.; Petersen, K.; O'shea, C.; Skriver, K., The Arabidopsis thaliana NAC transcription factor family: structure-function relationships and determinants of ANAC019 stress signalling. Biochemical Journal. 2010, $426(2), 183-196$.

17. Yoshiyama, K.; Conklin, P. A.; Huefner, N. D.; Britt, A. B., Suppressor of gamma response 1 (SOG1) encodes a putative transcription factor governing multiple responses to 
DNA damage. Proceedings of the National Academy of Sciences. 2009, 106 (31), 1284312848.

18. Chen, Q.; Wang, Q.; Xiong, L.; Lou, Z., A structural view of the conserved domain of rice stress-responsive NAC1. Protein \& cell. 2011, 2 (1), 55-63.

19. Fang, Y.; You, J.; Xie, K.; Xie, W.; Xiong, L., Systematic sequence analysis and identification of tissue-specific or stress-responsive genes of NAC transcription factor family in rice. Molecular Genetics and Genomics. 2008, 280 (6), 547-563.

20. Puranik, S.; Bahadur, R. P.; Srivastava, P. S.; Prasad, M., Molecular cloning and characterization of a membrane associated NAC family gene, SiNAC from foxtail millet [Setaria italica (L.) P. Beauv.]. Molecular biotechnology. 2011, 49 (2), 138-150.

21. Tran, L. S. P.; Nakashima, K.; Sakuma, Y.; Osakabe, Y.; Qin, F.; Simpson, S. D.; Maruyama, K.; Fujita, Y.; Shinozaki, K.; Yamaguchi-Shinozaki, K., Co-expression of the stress-inducible zinc finger homeodomain ZFHD1 and NAC transcription factors enhances expression of the ERD1 gene in Arabidopsis. The Plant Journal. 2007, 49 (1), 46-63.

22. Puranik, S.; Bahadur, R. P.; Srivastava, P. S.; Prasad, M., Molecular cloning and characterization of a membrane associated NAC family gene, SiNAC from foxtail millet [Setaria italica (L.) P. Beauv.]. Molecular biotechnology. 2011, 49 (2), 138-150.

23. Kim, H. S.; Park, B. O.; Yoo, J. H.; Jung, M. S.; Lee, S. M.; Han, H. J.; Kim, K. E.; Kim, S. H.; Lim, C. O.; Yun, D.-J., Identification of a calmodulin-binding NAC protein as a transcriptional repressor in Arabidopsis. Journal of Biological Chemistry. 2007, 282 (50), 36292-36302.

24. Yamaguchi, M.; Ohtani, M.; Mitsuda, N.; Kubo, M.; Ohme-Takagi, M.; Fukuda, H.; Demura, T., VND-INTERACTING2, a NAC domain transcription factor, negatively regulates xylem vessel formation in Arabidopsis. The Plant Cell. 2010, 22 (4), 1249-1263.

25. Kjaersgaard, T.; Jensen, M. K.; Christiansen, M. W.; Gregersen, P.; Kragelund, B. B.; Skriver, K., Senescence-associated barley NAC (NAM, ATAF1, 2, CUC) transcription factor interacts with radical-induced cell death 1 through a disordered regulatory domain. Journal of Biological Chemistry. 2011, 286 (41), 35418-35429.

26. Seo, P. J.; Kim, S.-G.; Park, C.-M., Membrane-bound transcription factors in plants. Trends in plant science 2008, 13 (10), 550-556.

27. Zhong, R.; Lee, C.; Ye, Z.-H., Global analysis of direct targets of secondary wall NAC master switches in Arabidopsis. Molecular plant. 2010, 3 (6), 1087-1103. 
28. Yang, S.-D.; Seo, P. J.; Yoon, H.-K.; Park, C.-M., The Arabidopsis NAC transcription factor VNI2 integrates abscisic acid signals into leaf senescence via the COR/RD genes. The Plant Cell. 2011, 23 (6), 2155-2168.

29. Christianson, J. A.; Dennis, E. S.; Llewellyn, D. J.; Wilson, I. W., ATAF NAC transcription factors: regulators of plant stress signaling. Plant signaling \& behavior. 2010, 5 (4), 428-432.

30. Tran, L.-S. P.; Nishiyama, R.; Yamaguchi-Shinozaki, K.; Shinozaki, K., Potential utilization of NAC transcription factors to enhance abiotic stress tolerance in plants by biotechnological approach. GM crops. 2010, 1 (1), 32-39.

31. Nakashima, K.; Takasaki, H.; Mizoi, J.; Shinozaki, K.; Yamaguchi-Shinozaki, K., NAC transcription factors in plant abiotic stress responses. Biochimica et Biophysica Acta (BBA)Gene Regulatory Mechanisms. 2012, 1819 (2), 97-103.

32. Nuruzzaman, M.; Manimekalai, R.; Sharoni, A. M.; Satoh, K.; Kondoh, H.; Ooka, H.; Kikuchi, S., Genome-wide analysis of NAC transcription factor family in rice. Gene. 2010, 465 (1-2), 30-44.

33. Avivi, Y.; Morad, V.; Ben-Meir, H.; Zhao, J.; Kashkush, K.; Tzfira, T.; Citovsky, V.; Grafi, G., Reorganization of specific chromosomal domains and activation of silent genes in plant cells acquiring pluripotentiality. Developmental dynamics: an official publication of the American Association of Anatomists. 2004, 230 (1), 12-22.

34. Grafi, G., How cells dedifferentiate: a lesson from plants. Developmental biology. 2004, $268(1), 1-6$.

35. Guo, M.; Rupe, M. A.; Danilevskaya, O. N.; Yang, X.; Hu, Z., Genome-wide mRNA profiling reveals heterochronic allelic variation and a new imprinted gene in hybrid maize endosperm. The Plant Journal. 2003, 36 (1), 30-44.

36. Bartel, D. P., MicroRNAs: genomics, biogenesis, mechanism, and function. Cell. 2004, 116 (2), 281-297.

37. Rhoades, M. W.; Reinhart, B. J.; Lim, L. P.; Burge, C. B.; Bartel, B.; Bartel, D. P., Prediction of plant microRNA targets. Cell. 2002, 110 (4), 513-520.

38. Kasschau, K. D.; Xie, Z.; Allen, E.; Llave, C.; Chapman, E. J.; Krizan, K. A.; Carrington, J. C., P1/HC-Pro, a viral suppressor of RNA silencing, interferes with Arabidopsis development and miRNA function. Developmental cell. 2003, 4 (2), 205-217. 
39. Mallory, A. C.; Dugas, D. V.; Bartel, D. P.; Bartel, B., MicroRNA regulation of NACdomain targets is required for proper formation and separation of adjacent embryonic, vegetative, and floral organs. Current Biolog.y 2004, 14 (12), 1035-1046.

40. Laufs, P.; Peaucelle, A.; Morin, H.; Traas, J., MicroRNA regulation of the CUC genes is required for boundary size control in Arabidopsis meristems. Development. 2004, 131 (17), 4311-4322.

41. Ruiz-Medrano, R.; Xoconostle-Cázares, B.; Lucas, W. J., Phloem long-distance transport of CmNACP mRNA: implications for supracellular regulation in plants. Development. 1999, 126 (20), 4405-4419.

42. Xie, Q.; Guo, H.-S.; Dallman, G.; Fang, S.; Weissman, A. M.; Chua, N.-H., SINAT5 promotes ubiquitin-related degradation of NAC1 to attenuate auxin signals. Nature. 2002, 419 (6903), 167-170.

43. Vierstra, R. D., The ubiquitin/26S proteasome pathway, the complex last chapter in the life of many plant proteins. Trends in plant science. 2003, 8 (3), 135-142.

44. Nakashima, K.; Ito, Y.; Yamaguchi-Shinozaki, K., Transcriptional regulatory networks in response to abiotic stresses in Arabidopsis and grasses. Plant physiology .2009, 149 (1), 88-95.

45. Jeong, J. S.; Kim, Y. S.; Baek, K. H.; Jung, H.; Ha, S.-H.; Do Choi, Y.; Kim, M.; Reuzeau, C.; Kim, J.-K., Root-specific expression of OsNAC10 improves drought tolerance and grain yield in rice under field drought conditions. Plant physiology. 2010, 153 (1), 185-197.

46. Udupa, S.; Robertson, L.; Weigand, F.; Baum, M.; Kahl, G., Allelic variation at (TAA) $\mathrm{n}$ microsatellite loci in a world collection of chickpea (Cicer arietinum L.) germplasm. Molecular and General Genetics MGG.1999, 261 (2), 354-363.

47. Balazadeh, S.; Siddiqui, H.; Allu, A. D.; Matallana-Ramirez, L. P.; Caldana, C.; Mehrnia, M.; Zanor, M. I.; Köhler, B.; Mueller-Roeber, B., A gene regulatory network controlled by the NAC transcription factor ANAC092/AtNAC2/ORE1 during salt-promoted senescence. The Plant Journal. 2010, 62 (2), 250-264.

48. Lan, L.; Li, M.; Lai, Y.; Xu, W.; Kong, Z.; Ying, K.; Han, B.; Xue, Y., Microarray analysis reveals similarities and variations in genetic programs controlling pollination/fertilization and stress responses in rice (Oryza sativa L.). Plant molecular biology. 2005, 59 (1), 151-164. 
49. Teng, S.; Keurentjes, J.; Bentsink, L.; Koornneef, M.; Smeekens, S., Sucrose-specific induction of anthocyanin biosynthesis in Arabidopsis requires the MYB75/PAP1 gene. Plant physiology 2005, 139 (4), 1840-1852.

50. Sindhu, A.; Chintamanani, S.; Brandt, A. S.; Zanis, M.; Scofield, S. R.; Johal, G. S., A guardian of grasses: specific origin and conservation of a unique disease-resistance gene in the grass lineage. Proceedings of the National Academy of Sciences. 2008, 105 (5), 17621767.

51. You, J.; Zong, W.; Li, X.; Ning, J.; Hu, H.; Li, X.; Xiao, J.; Xiong, L., The SNAC1targeted gene OsSRO1c modulates stomatal closure and oxidative stress tolerance by regulating hydrogen peroxide in rice. Journal of experimental botany. 2013, 64 (2), 569583.

52. Nuruzzaman, M.; Sharoni, A. M.; Satoh, K.; Moumeni, A.; Venuprasad, R.; Serraj, R.; Kumar, A.; Leung, H.; Attia, K.; Kikuchi, S., Comprehensive gene expression analysis of the NAC gene family under normal growth conditions, hormone treatment, and drought stress conditions in rice using near-isogenic lines (NILs) generated from crossing Aday Selection (drought tolerant) and IR64. Molecular genetics and genomics. 2012, 287 (5), 389-410.

53. Liu, Q.-L.; Xu, K.-D.; Zhao, L.-J.; Pan, Y.-Z.; Jiang, B.-B.; Zhang, H.-Q.; Liu, G.-L., Overexpression of a novel chrysanthemum NAC transcription factor gene enhances salt tolerance in tobacco. Biotechnology letters. 2011, 33 (10), 2073.

54. Karthik, L.; Kumar, G.; Keswani, T.; Bhattacharyya, A.; Chandar, S. S.; Rao, K. B., Protease inhibitors from marine actinobacteria as a potential source for antimalarial compound. PloS one. 2014, 9 (3).

55. Tang, Y.; Liu, M.; Gao, S.; Zhang, Z.; Zhao, X.; Zhao, C.; Zhang, F.; Chen, X., Molecular characterization of novel TaNAC genes in wheat and overexpression of TaNAC2a confers drought tolerance in tobacco. Physiologia plantarum. 2012, 144 (3), 210-224.

56. Jensen, M. K.; Rung, J. H.; Gregersen, P. L.; Gjetting, T.; Fuglsang, A. T.; Hansen, M.; Joehnk, N.; Lyngkjaer, M. F.; Collinge, D. B., The HvNAC6 transcription factor: a positive regulator of penetration resistance in barley and Arabidopsis. Plant molecular biology. 2007, 65 (1-2), 137-150.

57. Jensen, M. K.; Hagedorn, P. H.; De Torres-Zabala, M.; Grant, M. R.; Rung, J. H.; Collinge, D. B.; Lyngkjaer, M. F., Transcriptional regulation by an NAC (NAM-ATAF1, 
2-CUC2) transcription factor attenuates ABA signalling for efficient basal defence towards Blumeria graminis f. sp. hordei in Arabidopsis. The Plant Journal. 2008, 56 (6), 867-880.

58. Sun, L.; Zhang, H.; Li, D.; Huang, L.; Hong, Y.; Ding, X. S.; Nelson, R. S.; Zhou, X.; Song, F., Functions of rice NAC transcriptional factors, ONAC122 and ONAC131, in defense responses against Magnaporthe grisea. Plant molecular biology. 2013, 81 (1-2), 41-56.

59. Purkayastha, A.; Dasgupta, I., Virus-induced gene silencing: a versatile tool for discovery of gene functions in plants. Plant Physiology and Biochemistry. 2009, 47 (11-12), 967-976.

60. Scofield, S. R.; Nelson, R. S., Resources for virus-induced gene silencing in the grasses. Plant Physiology. 2009, 149 (1), 152-157.

61. Nguyen, H. P.; Chakravarthy, S.; Velásquez, A. C.; McLane, H. L.; Zeng, L.; Nakayashiki, H.; Park, D.-H.; Collmer, A.; Martin, G. B., Methods to study PAMPtriggered immunity using tomato and Nicotiana benthamiana. Molecular Plant-Microbe Interactions. 2010, 23 (8), 991-999.

62. van der Linde, K.; Kastner, C.; Kumlehn, J.; Kahmann, R.; Doehlemann, G., Systemic virus-induced gene silencing allows functional characterization of maize genes during biotrophic interaction with Ustilago maydis. New Phytologist. 2011, 189 (2), 471-483.

63. Badr, A.; Sayed-Ahmed, H.; El-Shanshouri, A.; Watson, L., Ancestors of white clover (Trifolium repens L.), as revealed by isozyme polymorphisms. Theoretical and Applied Genetic.s 2002, 106 (1), 143-148.

64. Iwata, H.; Gaston, A.; Remay, A.; Thouroude, T.; Jeauffre, J.; Kawamura, K.; Oyant, L. H. S.; Araki, T.; Denoyes, B.; Foucher, F., The TFL1 homologue KSN is a regulator of continuous flowering in rose and strawberry. The Plant Journal. 2012, 69 (1), 116-125.

65. Wang, X. e.; Basnayake, B. V. S.; Zhang, H.; Li, G.; Li, W.; Virk, N.; Mengiste, T.; Song, F., The Arabidopsis ATAF1, a NAC transcription factor, is a negative regulator of defense responses against necrotrophic fungal and bacterial pathogens. Molecular PlantMicrobe Interactions. 2009, 22 (10), 1227-1238.

66. Padmanabhan, M. S.; Goregaoker, S. P.; Golem, S.; Shiferaw, H.; Culver, J. N., Interaction of the tobacco mosaic virus replicase protein with the Aux/IAA protein PAP1/IAA26 is associated with disease development. Journal of virology. 2005, 79 (4), 2549-2558. 
67. Kaneda, T.; Taga, Y.; Takai, R.; Iwano, M.; Matsui, H.; Takayama, S.; Isogai, A.; Che, F. S., The transcription factor OsNAC4 is a key positive regulator of plant hypersensitive cell death. The EMBO journal. 2009, 28 (7), 926-936.

68. Nakashima, K.; Tran, L. S. P.; Van Nguyen, D.; Fujita, M.; Maruyama, K.; Todaka, D.; Ito, Y.; Hayashi, N.; Shinozaki, K.; Yamaguchi-Shinozaki, K., Functional analysis of a NAC-type transcription factor OsNAC6 involved in abiotic and biotic stress-responsive gene expression in rice. The Plant Journal. 2007, 51 (4), 617-630.

69. Delessert, C.; Kazan, K.; Wilson, I. W.; Straeten, D. V. D.; Manners, J.; Dennis, E. S.; Dolferus, R., The transcription factor ATAF2 represses the expression of pathogenesisrelated genes in Arabidopsis. The Plant Journal. 2005, 43 (5), 745-757.

70. Seo, P. J.; Kim, M. J.; Park, J. Y.; Kim, S. Y.; Jeon, J.; Lee, Y. H.; Kim, J.; Park, C. M., Cold activation of a plasma membrane-tethered NAC transcription factor induces a pathogen resistance response in Arabidopsis. The Plant Journal. 2010, 61 (4), 661-671.

71. Reise, S. P.; Waller, N. G., Item response theory and clinical measurement. Annual review of clinical psychology. 2009, 5, 27-48.

72. Fujita, M.; Fujita, Y.; Noutoshi, Y., Y, F. Takahashi, Y. Narusaka and K. YamaguchiShinozaki, “Crosstalk between Abiotic and Biotic Stress Responses: A Current View from the points of Convergence in the Stress Signaling Networks,". Current Opinion in Plant Biology. 2006, 9 (4), 436-442.

73. Taverner, N. V.; Smith, J. C.; Wardle, F. C., Identifying transcriptional targets. Genome biology. 2004, 5 (3), 210.

74. Hiratsu, K.; Matsui, K.; Koyama, T.; Ohme-Takagi, M., Dominant repression of target genes by chimeric repressors that include the EAR motif, a repression domain, in Arabidopsis. The Plant Journal. 2003, 34 (5), 733-739.

75. Singh, K. B., Transcriptional regulation in plants: the importance of combinatorial control. Plant Physiology. 1998, 118 (4), 1111-1120.

76. Sperotto, R. A.; Ricachenevsky, F. K.; Duarte, G. L.; Boff, T.; Lopes, K. L.; Sperb, E. R.; Grusak, M. A.; Fett, J. P., Identification of up-regulated genes in flag leaves during rice grain filling and characterization of OsNAC5, a new ABA-dependent transcription factor. Planta .2009, 230 (5), 985-1002.

77. Zheng, X.; Chen, B.; Lu, G.; Han, B., Overexpression of a NAC transcription factor enhances rice drought and salt tolerance. Biochemical and biophysical research communications. 2009, 379 (4), 985-989. 
78. Yoshii, M.; Yamazaki, M.; Rakwal, R.; Kishi-Kaboshi, M.; Miyao, A.; Hirochika, H., The NAC transcription factor RIM1 of rice is a new regulator of jasmonate signaling. The Plant Journal. 2010, 61 (5), 804-815.

79. Kim, S. G.; Lee, A. K.; Yoon, H. K.; Park, C. M., A membrane-bound NAC transcription factor NTL8 regulates gibberellic acid-mediated salt signaling in Arabidopsis seed germination. The Plant Journal. 2008, 55 (1), 77-88.

80. Bu, Q.; Jiang, H.; Li, C.-B.; Zhai, Q.; Zhang, J.; Wu, X.; Sun, J.; Xie, Q.; Li, C., Role of the Arabidopsis thaliana NAC transcription factors ANAC019 and ANAC055 in regulating jasmonic acid-signaled defense responses. Cell research. 2008, 18 (7), 756-767.

81. Lu, P.-L.; Chen, N.-Z.; An, R.; Su, Z.; Qi, B.-S.; Ren, F.; Chen, J.; Wang, X.-C., A novel drought-inducible gene, ATAF1, encodes a NAC family protein that negatively regulates the expression of stress-responsive genes in Arabidopsis. Plant molecular biology. 2007, 63 (2), 289-305.

82. Yokotani, N.; Ichikawa, T.; Kondou, Y.; Matsui, M.; Hirochika, H.; Iwabuchi, M.; Oda, K., Tolerance to various environmental stresses conferred by the salt-responsive rice gene ONAC063 in transgenic Arabidopsis. Planta. 2009, 229 (5), 1065-1075.

83. Lin, R.; Zhao, W.; Meng, X.; Wang, M.; Peng, Y., Rice gene OsNAC19 encodes a novel NAC-domain transcription factor and responds to infection by Magnaporthe grisea. Plant science. 2007, 172 (1), 120-130.

84. Faria, J. A.; Reis, P. A.; Reis, M. T.; Rosado, G. L.; Pinheiro, G. L.; Mendes, G. C.; Fontes, E. P., The NAC domain-containing protein, GmNAC6, is a downstream component of the ER stress-and osmotic stress-induced NRP-mediated cell-death signaling pathway. BMC plant biology. 2011, 11 (1), 129.

85. Collinge, M.; Boller, T., Differential induction of two potato genes, Stprx2 and StNAC, in response to infection by Phytophthora infestans and to wounding. Plant molecular biology. 2001, 46 (5), 521-529.

86. Huh, S. U.; Lee, S.-B.; Kim, H. H.; Paek, K.-H., ATAF2, a NAC transcription factor, binds to the promoter and regulates NIT2 gene expression involved in auxin biosynthesis. Molecules and cells. 2012, 34 (3), 305-313.

87. Saga, H.; Ogawa, T.; Kai, K.; Suzuki, H.; Ogata, Y.; Sakurai, N.; Shibata, D.; Ohta, D., Identification and characterization of ANAC042, a transcription factor family gene involved in the regulation of camalexin biosynthesis in Arabidopsis. Molecular plantmicrobe interactions. 2012, 25 (5), 684-696. 
88. Lee, S.; Seo, P. J.; Lee, H. J.; Park, C. M., A NAC transcription factor NTL4 promotes reactive oxygen species production during drought-induced leaf senescence in Arabidopsis. The Plant Journal. 2012, 70 (5), 831-844.

89. Yoon, H.-K.; Kim, S.-G.; Kim, S.-Y.; Park, C.-M., Regulation of leaf senescence by NTL9-mediated osmotic stress signaling in Arabidopsis. Molecules \& Cells (Springer Science \& Business Media BV). 2008, 25 (3).

90. de Zélicourt, A.; Diet, A.; Marion, J.; Laffont, C.; Ariel, F.; Moison, M.; Zahaf, O.; Crespi, M.; Gruber, V.; Frugier, F., Dual involvement of a Medicago truncatula NAC transcription factor in root abiotic stress response and symbiotic nodule senescence. The Plant Journal. 2012, 70 (2), 220-230.

91. Seo, P. J.; Park, C.-M., Signaling linkage between environmental stress resistance and leaf senescence in Arabidopsis. Plant signaling \& behavior. 2011, 6 (10), 1564-1566.

92. Guo, H. S.; Fei, J. F.; Xie, Q.; Chua, N. H., A chemical-regulated inducible RNAi system in plants. The Plant Journal. 2003, 34 (3), 383-392.

93. Greve, K.; COUR, T. L.; Jensen, M. K.; Poulsen, F. M.; Skriver, K., Interactions between plant RING-H2 and plant-specific NAC (NAM/ATAF1/2/CUC2) proteins: RING-H2 molecular specificity and cellular localization. Biochemical Journal. 2003, 371 (1), 97-108.

94. Robertson, M., Two transcription factors are negative regulators of gibberellin response in the HvSPY-signaling pathway in barley aleurone. Plant Physiology 2004, 136 (1), 27472761.

95. Hoppe, T.; Rape, M.; Jentsch, S., Membrane-bound transcription factors: regulated release by RIP or RUP. Current opinion in cell biology. 2001, 13 (3), 344-348.

96. Nair, R.; Carter, P.; Rost, B., NLSdb: database of nuclear localization signals. Nucleic acids research. 2003, 31 (1), 397-399.

97. La Cour, T.; Kiemer, L.; Mølgaard, A.; Gupta, R.; Skriver, K.; Brunak, S., Analysis and prediction of leucine-rich nuclear export signals. Protein Engineering Design and Selection. 2004, 17 (6), 527-536.

98. Cokol, M.; Nair, R.; Rost, B., Finding nuclear localization signals. EMBO reports 2000, 1 (5), 411-415.

99. Nakai, K.; Kanehisa, M., A knowledge base for predicting protein localization sites in eukaryotic cells. Genomics. 1992, 14 (4), 897-911. 
100. la Cour, T.; Gupta, R.; Rapacki, K.; Skriver, K.; Poulsen, F. M.; Brunak, S., NESbase version 1.0: a database of nuclear export signals. Nucleic acids research. 2003, 31 (1), 393396.

101. Mao, C.; Ding, W.; Wu, Y.; Yu, J.; He, X.; Shou, H.; Wu, P., Overexpression of a NAC-domain protein promotes shoot branching in rice. New Phytologist. 2007, 176 (2), 288-298. 